\title{
To Be or Not to Be...? Part II: Is Global Climate Change a Reality or a Means of Slavery?
}

\author{
Ilia Brondz \\ Norwegian Drug Control and Drug Discovery Institute (NDCDDI), Ski, Norway \\ Email: ilia.brondz@gmail.com
}

L'Etat, c'est moi" ("I am the State"). Louis XIV, King of France

How to cite this paper: Brondz, I. (2017) To Be or Not to Be...? Part II: Is Global Climate Change a Reality or a Means of Slavery? Voice of the Publisher, 4, 1-12. https://doi.org/10.4236/vp.2018.41001

Received: January 3, 2018

Accepted: March 9, 2018

Published: March 12, 2018

Copyright $\odot 2018$ by author and Scientific Research Publishing Inc. This work is licensed under the Creative Commons Attribution-NonCommercial International License (CC BY-NC 4.0). http://creativecommons.org/licenses/by-nc/4.0/

\begin{abstract}
This paper is a development of ideas presented in a previous publication, "To be or not to be...? Part I. Does global climate change a future reality?" The events that occurred in the world after the publication of Part I in this series have supported the idea that celestial influences on the earth's climate prevail above all other influences. Some negative influence on the climate may arise from the destruction of air streams that have naturally existed for thousands of years in the Atlantic by the growing number of wind power plants. This development, which is harmful for the environment, was propagated by hysteria relating to "global climate change". This will be discussed in this paper, in addition to the issues already presented previously in Part I, regarding the harm created by "fire-stick farming". The hysteria relating to "global climate change" is mainly propagated by, and for, the big business corporations-which are "the State" and "the Law" on Earth-to drain the world's population and some of the oil producing countries of money. This hysteria commenced as a social, geopolitical, and economic event, directed against militarization of the Russian Federation by using the oil money, and against some socially undesirable regimes as it was in Venezuela. Generally, big money-holders govern beyond the laws and the national governments. They would like to impose an additional economical yoke on the population of the earth.
\end{abstract}

\section{Keywords}

Global Climate Change, Events in the Mexican Gulf, Earthquake in Mexico, Hot Summer in Southern Europe, Cold Summer in Northern Europe 


\section{Introduction}

Humans as a species are the most numerous mammals on earth. They are the most dangerous of all predators and the most destructive species in terms of nature and the environment destruction. Although humans have referred to themselves as the "Kings of nature", their recent struggles with the forces of nature indicate otherwise. The events that occurred in the Mexican Gulf and Caribbean Sea during September 2017, involving localized, though stronger than normal, winds and rain, indicated that this "King of nature" was not only a "Naked king", but a simple "mini midget". Despite humans having given themselves the title of "global climate correctors", they were not able do anything to stop the destructive wind and rain. Of course, the "King of nature" can destroy localized areas of nature, kill entire species of precious animals, destroy large areas of vegetation, and even annihilate entire seas, as shown by the example of the Aral Sea. Do humans have the power to change the local climate situation? The answer is yes. Do they have the power to change the global climate? The answer is no!

\subsection{Do Humans Have the Power to Change the Local Climate Situation?}

In prehistoric times, cold periods alternated with periods of warming, and even with periods of extreme warming. The "King of nature", according to the materialistic theories of Marx and Darwin, began life as a "nutrient chicken broth", which, with its growing ambitions to govern over all, became a "veal tea" and, later, a "beef tea". Over time, as its ambitions to govern became significantly larger, the "beef tea" became a chimpanzee. With head-bracing speed, according to Darwin's theories, the chimp became the "King of nature". One of the great actions performed by this "chimp King of nature" was altering the climate of Chad, in Africa, from a dwelling place suitable for crocodiles and hippopotamuses to a dry desert, in which even camels find it difficult to sustain themselves. Similarly, North Africa around the ancient Carthage, which was a blooming land according to the historiographers of the time, became a poor semi-desert, and the Aral Sea, which had been full of fish, became a dry salted land and salt desert. Further, the "chimp" has begun to build thousands of wind power stations that have reduced the strength, speed, and density of the northern wind from the Arctic. As a result, the warm African winds were able to enter southern Europe. The year 2017 had a warm summer in southern Europe, but a cold spring, summer, and autumn in northern Europe because of the resistance of thousands of wind power stations to the Arctic winds, wind power stations prevented Arctic winds in progressing forward in their normal direction. The results of these actions are presented in Figures 1-4, which focus on a location $35 \mathrm{~km}$ south of Oslo, Norway, and $37 \mathrm{~m}$ above sea level. In 1970 and 1971, corn was harvested at this place on August 16. The harvesting of corn at this place in the middle of August was the normal procedure for many years. However, in 


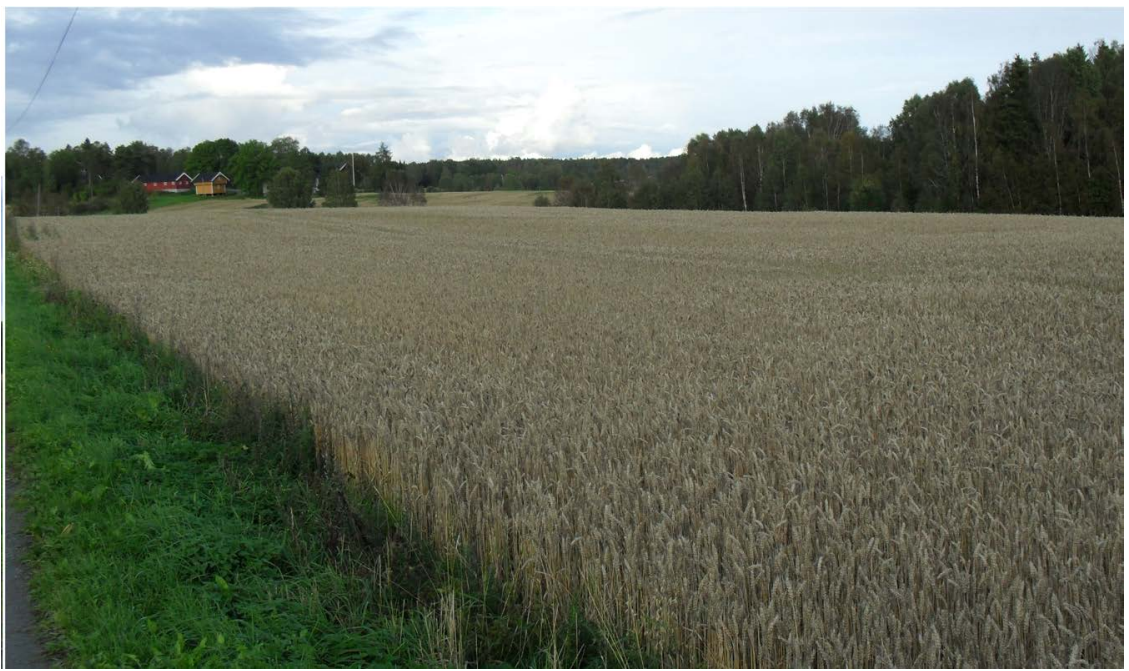

Figure 1. A corn field $35 \mathrm{~km}$ south of Oslo, Norway, on September 20, 2017. Photograph by the author.

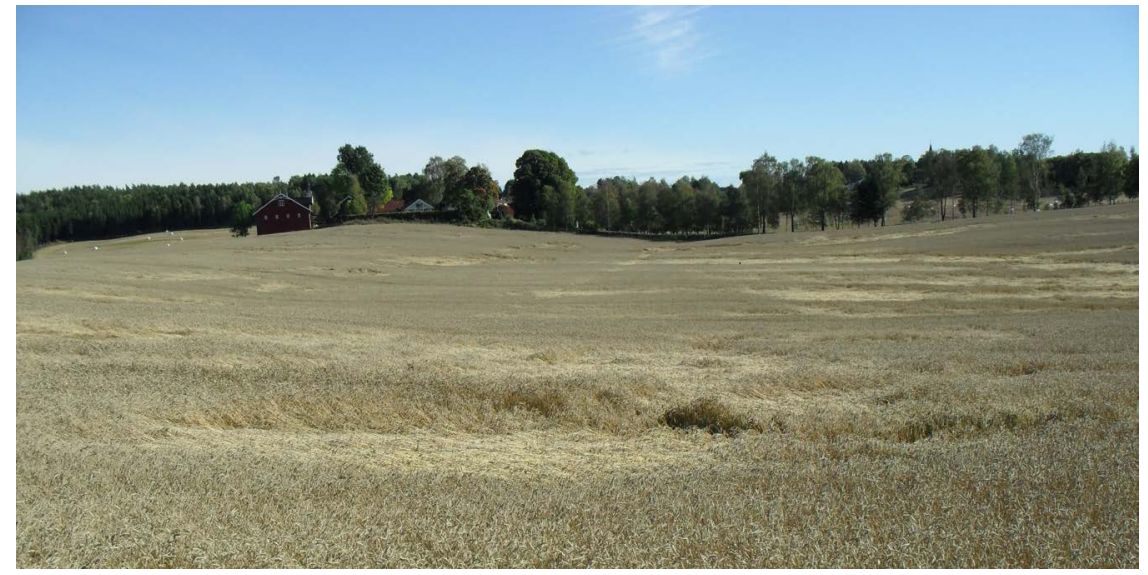

Figure 2. The same location in Norway, shown in Figure 1, on September 24, 2017. The corn is lying on the ground in many places. Photograph by the author.

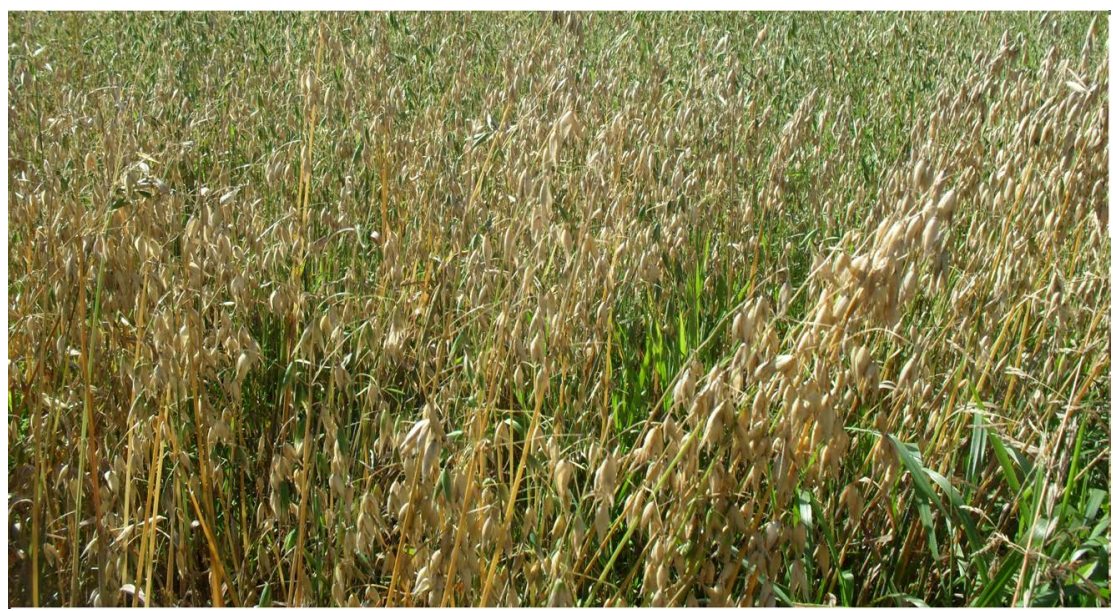

Figure 3. Photograph taken on September 20, 2017, in an oat field, near the Norwegian location shown in Figure 1. The oats are green and overgrown with grass. Photograph by the author. 


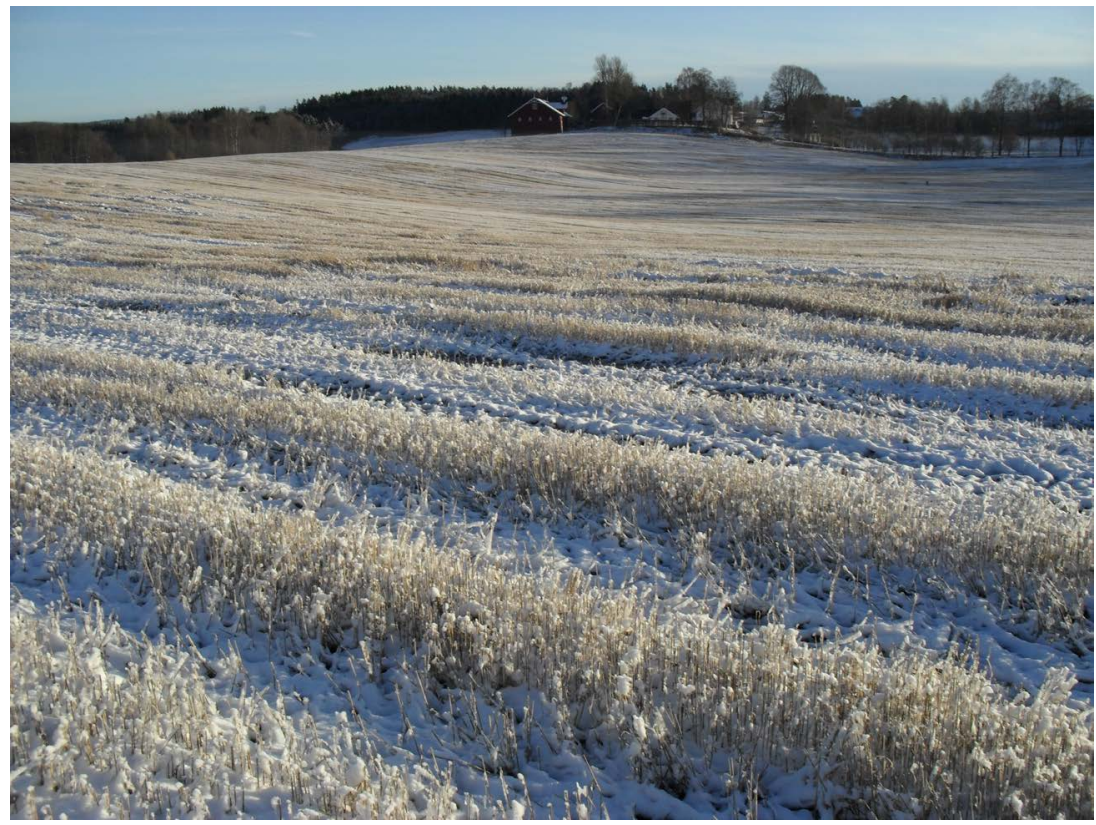

Figure 4. The corn field shown in Figure 1 and Figure 2 is covered by snow at November 10, 2017. Photograph by the author.

2017, the harvest was delayed by more than a month because of the cold and rainy weather. It is likely that this weather was created by the activities of the "King of nature", described above. That is, the explanation for the cold and rainy weather is that the "King of nature" prevented the Artic winds from progressing in their usual direction. Figure 1 presents the location described. A detailed explanation of the changes in climate experienced there, and their effects, follows.

The same location is shown in Figure 2, after several days of rainy, cold, and humid weather.

Oats were usually harvested a week before corn in the region. However, the photograph in Figure 3 shows that the field of oats was green and overgrown by grass.

Returning to the discussion of the corn field, less than one month after the corn was harvested, the location was covered with snow, during autumn, as shown in Figure 4.

The same corn field later that autumn is shown in Figure 5, when the temperature was $10^{\circ} \mathrm{C}$ on November 23, 2017. The grass was beginning to grow among the corn stubs in the field. Farmers would not have been able to sow their winter corn crop in this situation because the sown corn would have rotted in the humid ground.

Very rarely, temperatures above zero degrees do occur in Norway in November because the Norwegian coast is warmed by the Gulf Stream. However, the combination of a cold and rainy spring, summer, and autumn all together is very rare. I cannot recollect such a situation occurring over the last 45 years.

\subsection{Can Solar and Moon Gravitation Cause Climate Changes?}

When the first paper in this series, "To Be or Not to Be...? Part I: Is Global Climate 


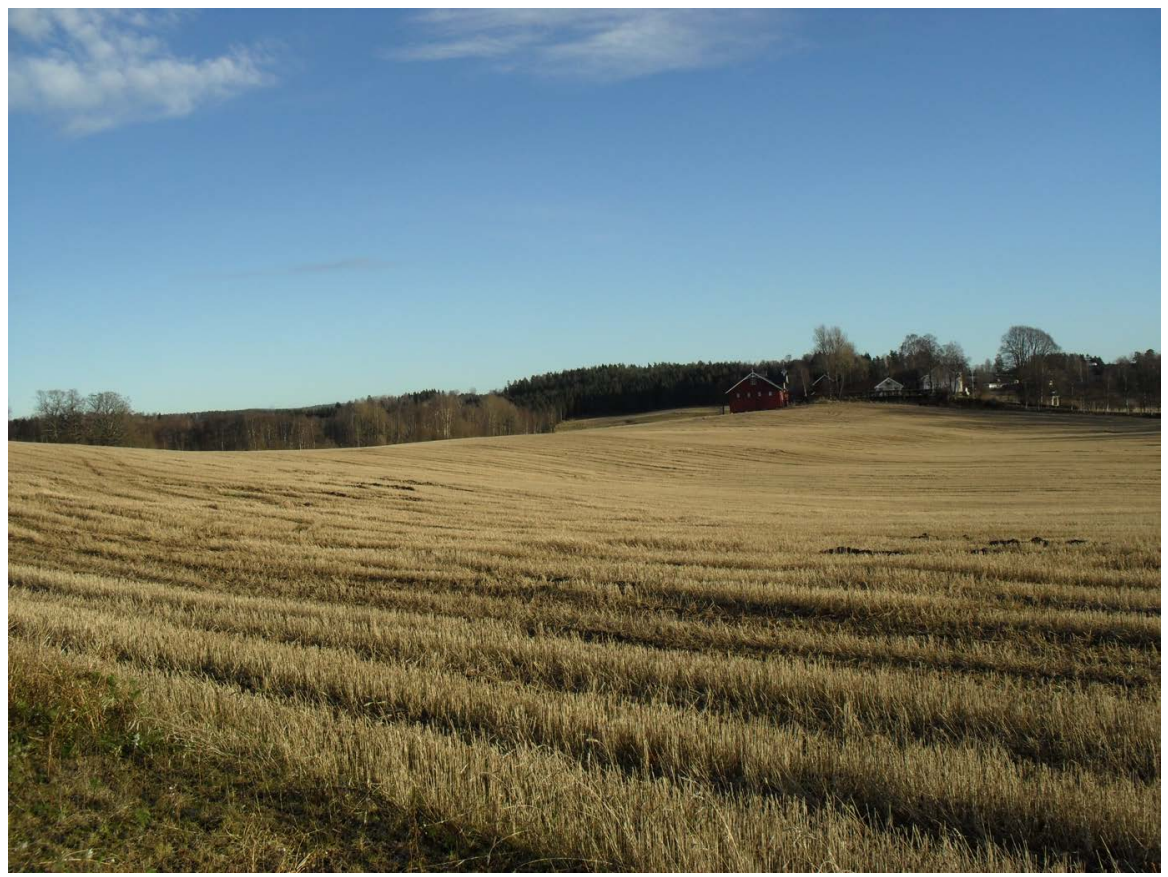

Figure 5. The corn field on November 23,2017 , when the temperature was $10^{\circ} \mathrm{C}$. Photograph by the author.

Change a Future Reality?” [1], was in press, two events occurred on planet Earth that strongly supported the contentions therein. First, a magnitude 7.1 earthquake hit Mexico [2], followed by a series of quakes. This powerful earthquake shook south-southwest of the city of Puebla and the surrounding states (and Mexico City) on September 19, 2017 [3]. Then, one week afterwards, an earthquake of magnitude 8.1 occurred off the southern coast of the country.

In paper 1, paragraph 1.1 discussed the topic "Can a Supermoon cause climate changes by initiating earthquakes and volcanic eruptions?" and noted that "December 2016 was a Supermoon period" [1]. The closest full moon of the twenty-first century fell on December 6, 2016 [4]. In [4], an important phenomenon among five major ones was discussed: that "Supermoon can create super tides". This refers to tides involving the oceans. However, another phenomenon arises from Supermoon: "what effect is there on the fluid portion of Earth's outer core, its magma [5] and "the solid portion of its inner core" [6]. Are they indifferent to the gravitational fluctuations of a Supermoon? The total solar eclipse of August 21, 2017 over North America [7] involved a constellation of the earth, moon, and sun, in which a straight line was created with the moon and the sun from one side of the earth [1]. Even in ancient Egypt, more than 2500 years ago, B.C., temple priests could calculate the time of Supermoon and solar eclipses. They also knew that these events could correlate with some unpleasant events on Earth. The earthquakes in Mexico could have been easily predicted. Magma is denser than water-it has about seven to nine times the density of water-and it is more viscous. Because of this, it is more inert to movement than water, and the time of magmatic tides experiences some delay compared with the time of 
water tides in the ocean. Figure 6 shows the additional magmatic movement created by the gravitational effects from the Supermoon in 2016-17. Figure 7 shows the additional magmatic movement created by gravitational effects from the solar eclipse of August 21, 2017 over North America. In Figure 8, the combined effect of these events is shown. The total solar eclipse of August 21, 2017 was observed in a region close to a region of friction between two tectonic plates. The Caribbean plate and the Cocos plate were pushed together from one side by the Nazca plate and the Pacific plate, and from the other side by the North American plate.

Additional magmatic movement created by gravitation

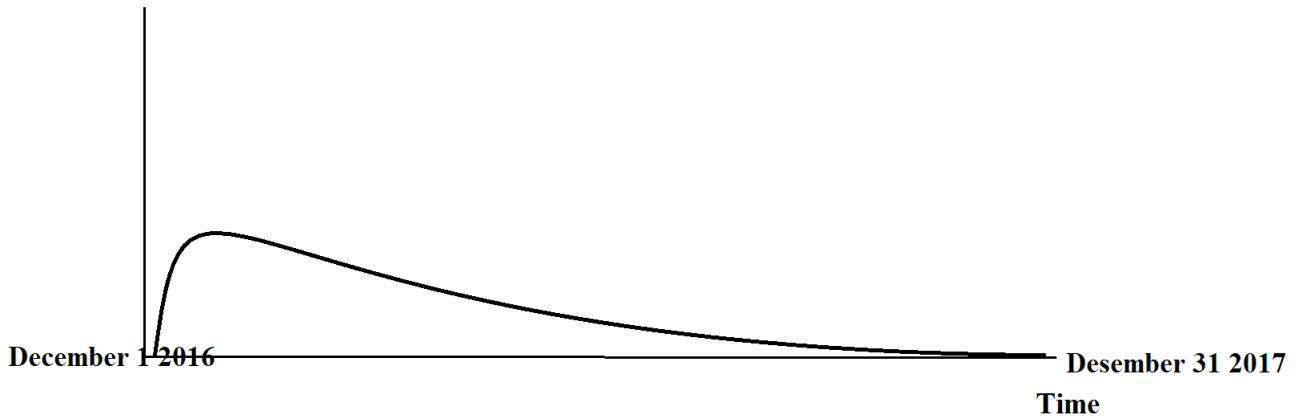

Figure 6. Additional magmatic movement created by the gravitational effects of the Supermoon in 2016-17.

Additional magmatic movement created by gravitation

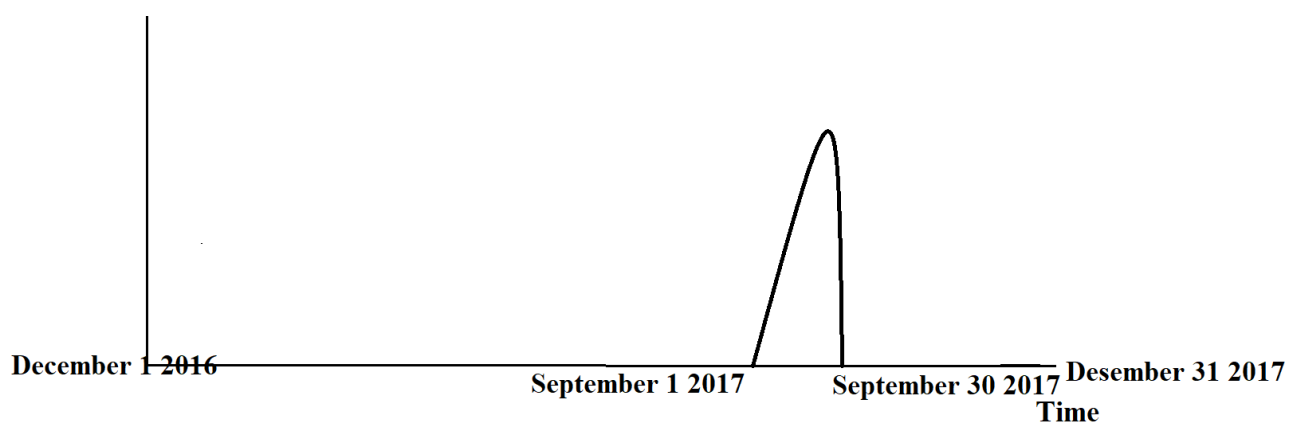

Figure 7. Additional magmatic movement created by the gravitational effects from the solar eclipse of August 21, 2017 over North America.

Additional magmatic movement created by gravitation

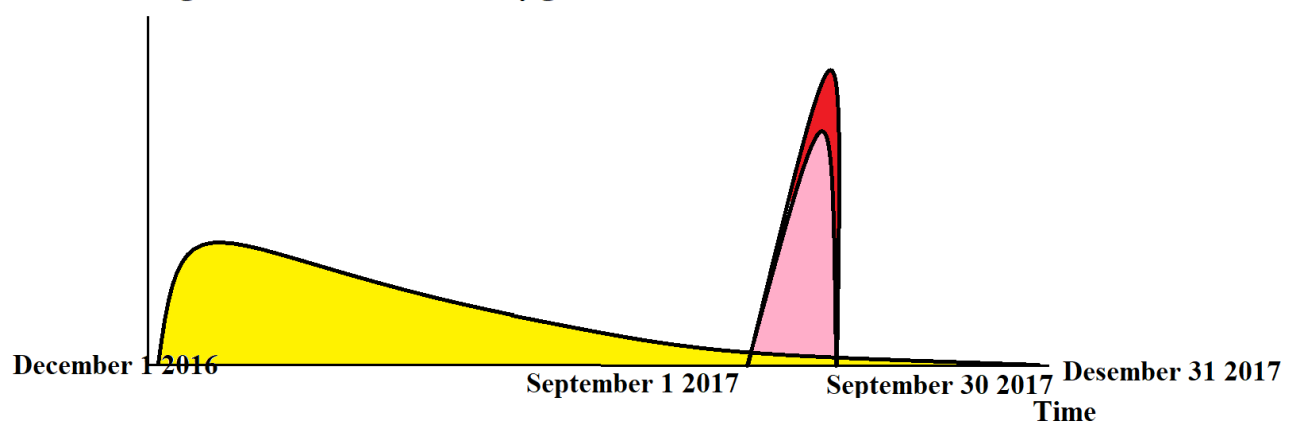

Figure 8. Combined effect of the events presented in Figure 6 and Figure 7, as indicated by the red area. 
More than 3000 years before these events occurred, it was possible for humans to predict celestial constellations and correlate these with unpleasant events on the earth. Today, there is additional knowledge regarding the boundaries of tectonic plates that can contribute to predicting earthquakes created by the alignment of the moon and sun. Thus, all the loud voices about the sudden occurrence of the disasters that occurred were nothing more than a smokescreen to cover the criminal idleness of the governing authorities. The hurricanes in the Caribbean and over the southern part of the US in September 2017 were also the result of the alignment of the moon and sun and the close distance of the moon to the earth. In the ocean of the air, as in the water ocean, there are tides created by the alignment of the moon and sun. It should not be a surprise that significant air tides occur over the places where there is a sun eclipse at a time close to a Supermoon.

\subsection{Use of Wind Energy}

The use of wind energy in nature is well known. The examples are many. Wind is used for the spreading of seeds, with the maple tree (the sycamore maple or Acer pseudoplatanus) being one species that uses wind to spread its seeds. The seeds, shown in Figure 9, have a flattened wing of fibrous, papery tissue and have been named maple keys, helicopters, and whirly-birds [8].

Maple trees are well represented all over the northern hemisphere and far into the south. It is no surprise that the seeds of the maple tree inspired people to form sails to enable boats to travel using the wind. A later development inspired by maple seeds was the construction of windmills. However, in earlier times, windmills represented a negligible part of the overall extent of wind power. In contrast, today's use of wind power, which continues to grow, creates significant barriers and resistance to the natural, established wind channels.

\subsection{Use of Solar Power by Nature}

The sun is a major provider of energy to the earth [1]. In nature, the use of solar

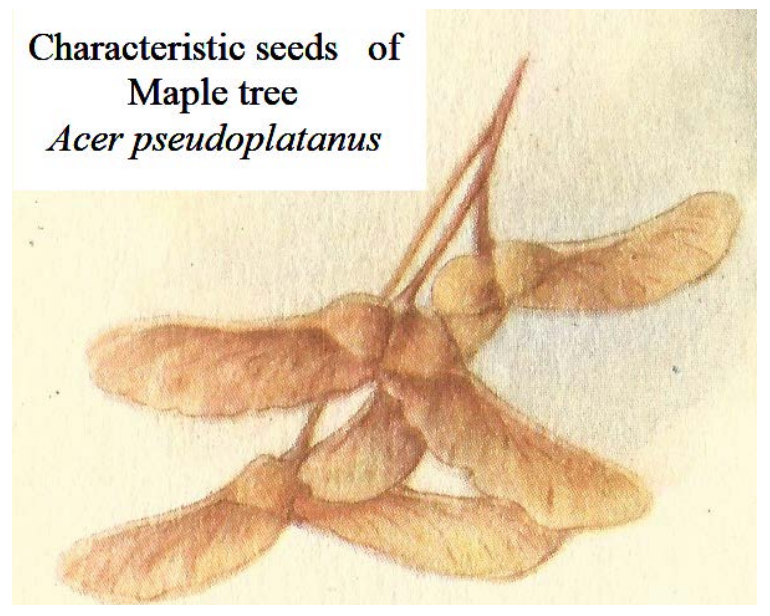

Figure 9. Characteristic seeds of the maple tree. 


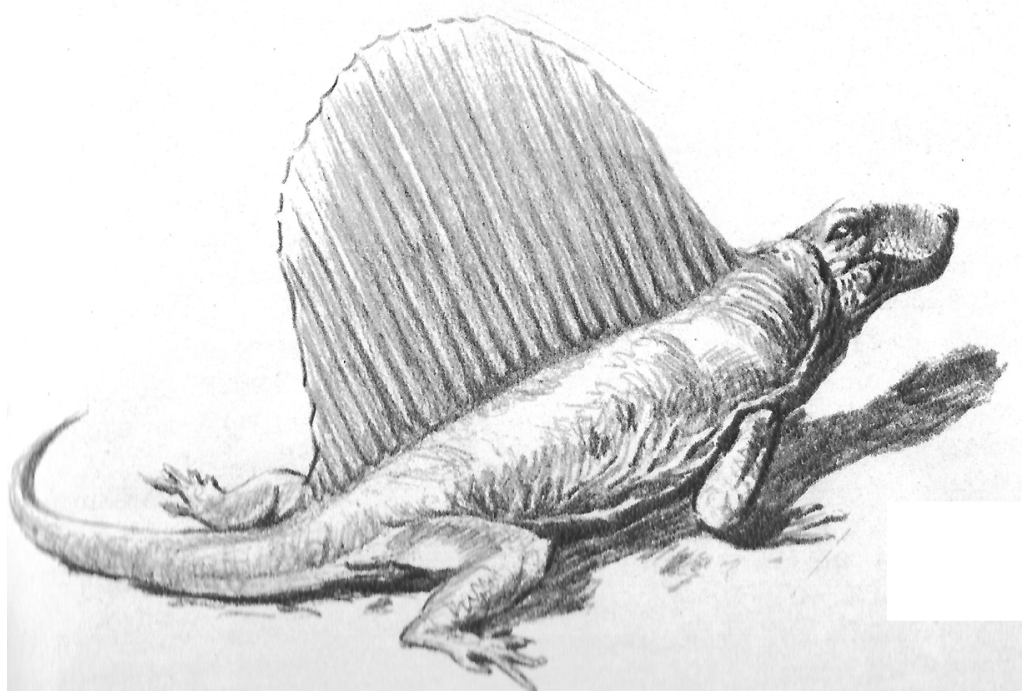

Figure 10. The Dimetrodon and its solar-powered battery.

energy is common. In addition to plants, animals have used solar energy for millions of years. A well-developed solar battery was on the back of the Dimetrodon, a member of the family Sphenacodontidae, shown in Figure 10. It had a large neural spine-sail on its back, shaped from elongated spines, covered with skin, which supported blood-vessels. The device did not contaminate nature and it was renewable, in the sense that, although it decayed and returned to the earth after the creature's death, the creature gave birth to another of its type during its lifetime.

\subsection{Use of Solar Power Today}

In the desert areas of Asia and Africa, the sand is heated by the sun to high temperatures, to such an extent that the indigenous population learned to bury birds' eggs in the sand to cook them. In more modern societies around the Mediterranean Sea (including Lebanon, Jordan, Israel, and Egypt), water-boiling tanks were already utilizing solar power at the beginning of the 1950s. In Israel, the sun is a major source of hot water from water-boiling tanks for kitchens, bathrooms, and common uses, as shown in Figure 11.

Sun energy is used to warm copper tubes in this device, which then warm the water that flows through the tubes. Apart from copper, iron, and a very small amount of plastic, there are no substances that could contaminate the environment. The lifetime of the tanks is several decades. They provide hot water even during winter or in cloudy weather, and no external energy apart from that provided by the sun is required for the devices' operation. Nearly every house in Israel has such a tank on its roof, as shown in Figure 12. Because these devices are placed on house roofs, they do not encroach on agricultural areas, parks, or commercial or trading areas. In neighboring Arab areas, the water-boiling tanks are also very popular, although the beautiful architecture of Arab houses does not always allow for the use of the devices because of absence of flat roofs. 


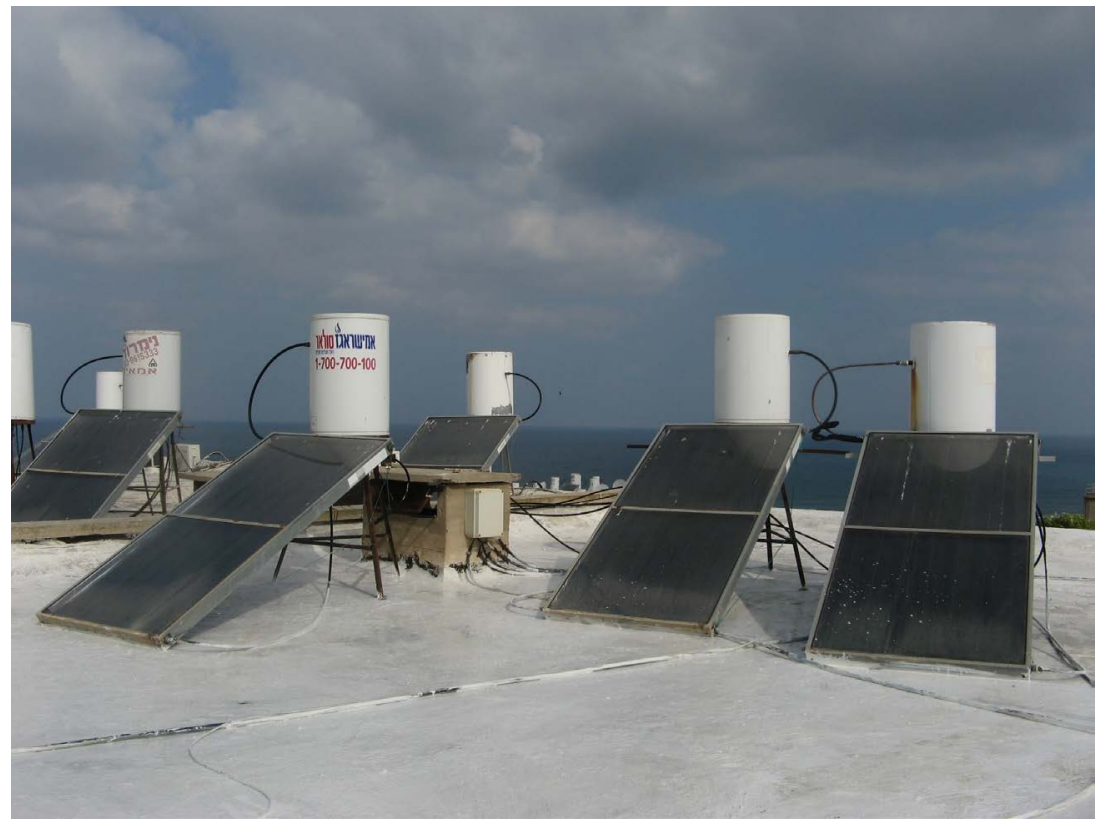

Figure 11. The water-boiling tanks consist of a so-called mirror, which is a cage covered with translucent plastic, inside of which are a number of copper tubes that lead the water to the collecting tank. Photograph by the author.

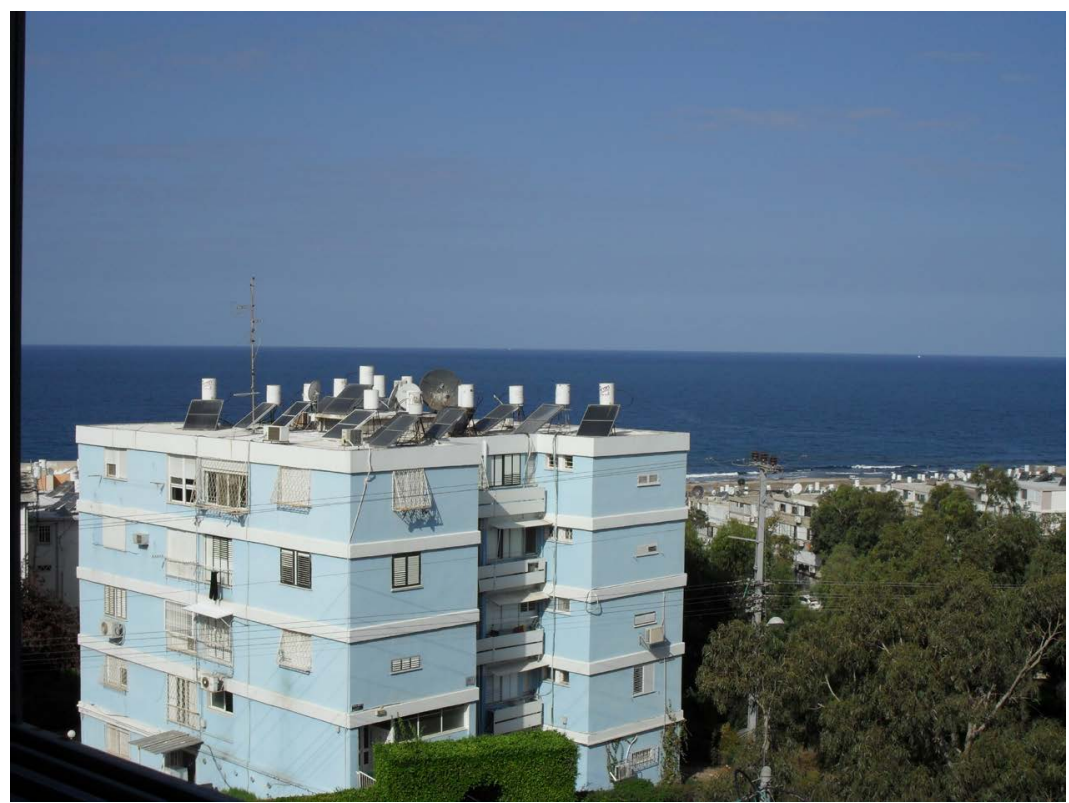

Figure 12. A house in Haifa, Israel, with water-boiling tanks on the roof. Photograph by the author.

\subsection{The Use of Solar Power by Solar Cell Devices Based on Electronic Components}

Nowadays, the use of solar power is based on electronic components produced by a growing electronics industry. First, silicon wafers [9] are manufactured and used to make silicon mirrors [10]. The use of solar power to-day often involves absurdities. Here, we examine the economic needs that drove the development 
of today's solar power industry, the absurdity of some of the solar devices developed, and the effects of the industry, which include the spoliation of land and damage to health and the environment.

\subsubsection{The Economic Needs}

The electronic components used in solar cells are semiconductors: the same devices that we have in our computers, phones, and televisions. The only difference is that a single solar cell element in solar-powered battery is the entire silicon mirror. Only a small number of viable semiconductors for use in computers, phones, or televisions, can be selected and cut from a good silicon mirror. For military use, the quality of semiconductors is more stringent, such that several silicon mirrors would be required to produce a single usable chip. In the past, most silicon mirrors were wasted because they were considered unusable, until the idea arose of using silicon mirrors in solar-powered cells. It was considered that this would provide a use for the otherwise wasted silicon mirrors, as well as providing economic advantages to the electronics industry. Of course, the use of this product as solar cells required massive propagation.

\subsubsection{The Absurdities of Some Devices Which Have been Driven by Solar Cells/Solar-Powered Battery}

Recently, an airplane powered by solar cells was presented as a technical miracle. Although it was widely publicized in the mass media [11], information about this airplane essentially involved cheating the public. Civil, cargo, and military aviation was developed for high-speed transportation. What tourist, business person, or military person would be willing to devote months instead of minutes or hours to reach his/her target destination? Who would wish to spend a month traveling from Europe to America? How many liters of water and how many kilograms of food must be loaded onto this plane even just for one person, given its extended flying time? How many kilograms of feces were produced by the pilots of this plane during the actual trip? Could the plane carry this cargo without many stops to gather supplies? It is known that aviation generally depends on good weather. However, an airplane powered by solar cells is more like a glider and it is totally dependent on good, calm weather to perform its flight. Moderate-strength winds would prevent this airplane to take off. Some useful devices powered by solar cells have been constructed, yet a great many are absurd, like this airplane.

\subsubsection{Spoliation of Areas Caused by the Placement of Solar Cell Devices Producing Electricity}

To date, most of the devices producing solar power have been placed in Europe's agricultural fields, not in the hot deserts. This has resulted in a reduction in the production of grain by Europe. With new producers including Brazil and India supplying the global grain market, in addition to the long-established producers in the US, Canada, and Australia, the over-production of grain was inevitable, particularly when Russia and China are self-supplying. Channeling of the food 
supply by the United Nations to terrorist organizations such as Hamas (in Gaza) or to African tribes' Hutu terrorist (insurgencies in Yemen, against Arabic indigenous population) was not sufficient to resolve the grain overproduction situation, and a new approach was required. A reduction of the grain production by industrialized Europe was needed. The spoliation of the agricultural areas of Europe by placing solar cells on numerous square kilometers was the answer to the overproduction of grain on the global market.

\subsubsection{Damage to Human Health and the Environment as a Result of the Massive Production of Solar Cells}

In section 1.6.1 above, it was noted that silicon mirrors are a major component of solar cells. The production of silicon mirrors [10] involves many steps, from the melting of silicium to the production of a silicon wafer [9], and finally, production of the silicon mirror [10]. Many wafers/silicon mirrors have defects and cannot be used to manufacture chips for electronic devices. However, they can be used in solar cells. The production of silicon mirrors and silicon wafers involves the use of many highly toxic substances, some of them known to the public and presented in [9], including boron, phosphorus, arsenic, and antimony. However, the use of the most toxic substances, including beryllium, thorium, germanium, gallium and organic liquids for cleaning and polishing, has been kept secret, hidden from public knowledge (as in Wikipedia [12] [13] [14]), because these substances are very damaging to humans and their environmental surroundings. The toxic substances as: beryllium is usually used in the preparation of beryllium ceramics for chips and doping siliceous crystals, thorium for sensitizing and elevation of electron/X-ray flow production in devices, selenium for doping, and barium for doping and for evacuation of oxygen. The numerous organic liquids are used in polishing, cleaning, removal of dirt, and in many other processes for finalizing and packing the final products in plastic containers. Most of these toxins have been dispatched in the environment and have resulted in genetic disorders in mammals and humans, such as born with six fingers, double heads, one eye in the forehead, a hole in the myocardium, and so on.

\section{Discussion}

At present, the footprint created by the production and use of solar cell devices producing electricity on a global basis (excluding military and space exploration use) is an area of $10-30 \mathrm{~km}^{2}$. The amount of toxic waste dispatched into the environment is significant; however, it is not critical. If hysteria about the need to "regulate the climate" leads to the abolishment of the use of mineral energy resources, the need for "renewable energy" based on solar cells will result in increased demand for the production of silicon mirrors. As a result, production would rise such that the footprint increased from $30 \mathrm{~km}^{2}$ to more than 10,000 $\mathrm{km}^{2}$. Although this situation would greatly benefit the electronics industry, the level of toxins produced will be more harmful to the planet, the amount of toxic 
waste dispatched into the environment will be not sustainable for life on planet.

There are signatures of 190 state leaders under Paris agreement. They would like to impose an additional economical yoke on the population of the earth. Only one courageous and wise leader the President of United State of America Donald John Trump opposed this destructive action.

\section{References}

[1] Brondz, I. (2017) To Be or Not to Be...? Part I: Is Global Climate Change a Future Reality? Voice of the Publisher, 3, 25-33. https://doi.org/10.4236/vp.2017.33003

[2] Agren, D. and Lakhani, N. (2017) At Least 225 Dead after Powerful Earthquake Hits Central Mexico. The Guardian.

https://www.theguardian.com/world/2017/sep/19/mexico-city-earthquake-annivers ary-1985

[3] Chavez, N., Almasy, S., Sanchez, R. and Simon, D. (2017) Central Mexico Earthquake Kills More than 200, Topples Buildings. CNN.

http://edition.cnn.com/2017/09/19/americas/mexico-earthquake/index.html

[4] Byrd, D. (2016) 5 Keys to Enjoying the Closest Supermoon. EarthSky Updates on Your Cosmos and World.

http://earthsky.org/astronomy-essentials/closest-supermoon-since-1948-nov-13-14$\underline{2016}$

[5] Wikipedia. https://en.wikipedia.org/wiki/Outer_core

[6] Wikipedia. https://en.wikipedia.org/wiki/Inner_core

[7] http://www.eclipse2017.org/2017/viewing_areas.htm

[8] van Gelderen, C.J. and van Gelderen, D.M. (1999) Maples for Gardens: A Color Encyclopedia.

https://www.amazon.com/Maples-Gardens-Encyclopedia-C-J-Gelderen/dp/088192 $\underline{4725}$

[9] Silicon Valley Microelectronics. https://www.svmi.com/silicon-wafer-manufacturing-semiconductor-process/

[10] Riekerink, M.B.O., Lansdorp, B., de Vreede, L.J., Blom, M.T., van’t Oever, R., Ackermann, M.D., Collon, M.J., Wallace, K. and Bavdaz, M. (2009) Production of Silicon Mirror Plates. SPIE Optical Engineering.

https://www.spiedigitallibrary.org/conference-proceedings-of-spie/7437/74370U/Pr oduction-of-silicon-mirror-plates/10.1117/12.825960.short?SSO=1\#ArticleLink

[11] Solar Plane Makes History after Completing Round-The-World Trip. https://www.theguardian.com/environment/2016/jul/26/solar-impulse-plane-makes -history-completing-round-the-world-trip

[12] Wikipedia. https://en.wikipedia.org/wiki/Silicon

[13] Wikipedia. https://en.wikipedia.org/wiki/Semiconductor

[14] Wikipedia. https://en.wikipedia.org/wiki/Siliconcarbide 